\title{
The Sensitivity and Specificity of Kuesioner Praskrining Perkembangan to Detect Delayed Development in Children
}

\author{
I. Gusti Ayu Trisna Windiani", I Gusti Agung Ngurah Sugitha Adnyana, Soetjiningsih
}

Department of Child Health, Medical Faculty of Udayana University, Sanglah Hospital, Denpasar, Indonesia

Email address:

trisnawindianidr@yahoo.co.id (I. G. A. T. Windiani)

${ }^{*}$ Corresponding author

\section{To cite this article:}

I. Gusti Ayu Trisna Windiani, I Gusti Agung Ngurah Sugitha Adnyana, Soetjiningsih. The Sensitivity and Specificity of Kuesioner Praskrining Perkembangan to Detect Delayed Development in Children. American Journal of Pediatrics. Vol. 6, No. 1, 2020, pp. 42-45.

doi: 10.11648/j.ajp.20200601.17

Received: February 2, 2020; Accepted: February 14, 2020; Published: February 21, 2020

\begin{abstract}
Kuesioner Praskrining Perkembangan (KPSP) is Indonesian child development pre-screening questionnaire. One method that is very easy and quick to detect early developmental deviations is the pre-screening method. A pre-screening device must has validity, reliability, sensitivity, specificity, acceptability and suitability to local conditions. The accuracy of KPSP has not been assessed adequately. The aim of this study was to assess the sensitivity and specificity of KPSP as a prescreening tool for children development compare to Capute Scales. We conducted KPSP diagnostic study, using Capute Scales test as gold standard. Subjects were children aged 3 to 24 months old who came for routine vaccination in Public Healthcare Centre South Denpasar from March until May 2018. Inclusion criteria were children aged 3 to 24 months whom agreed to be participate, while the exclusion criteria were children with Down syndrome, congenital hypothyroid, cerebral palsy, autisms spectrum disorder or mayor congenital disorder. One hundred twenty-seven were included after the exclusion of 5 children who fulfilled the inclusion criteria. Kuesioner Praskrining Perkembangan (KPSP) had 75\% sensitivity, $99.16 \%$ specificity, $85.71 \%$ positive predictive value (PPV) and 98.33\% negative predictive value (NPV). Kuesioner Praskrining Perkembangan (KPSP) has good sensitivity and specificity to detecting developmental deviations in children with Capute Scales as the gold standard.
\end{abstract}

Keywords: Kueisioner Praskrining Perkembangan, Delayed Development, Capute Scale, Children

\section{Introduction}

Children are valuable nation's investment for the future, therefor good quality children are needed to achieve good future. Good growth and development are absolute requirements to achieve optimal health status. The disruption of growth and development will hinder the creation of good quality human resources which determine the future of nation and state development.

The first thousand days of life is a crucial period in monitoring children's growth and development. This period is often referred as the golden period or window opportunities. The first thousand days of life, starts since conception in mother's womb until the child is 2 years old. [1] The process of growth and development of children occurs rapidly in that period. The child's brain has reached $80 \%$ of adults at the age of 2 years old. [2] The growth and development monitoring in the first 2 years of life must be done in every child, to detect any problem or disorder, immediate action is given.

The Health Ministry of Republic Indonesia, 2010 stated that from 500 measured children for growth and development, 97 children experienced growth and development disorders. [3] Suwarba et al (2008), found the prevalence of global developmental delay $2.3 \%$ from 6,487 children patients whom visited at the Pediatric's Neurology outpatient clinic in Dr. Cipto Mangunkusumo hospital Jakarta. [4] The most complaints were unable to walk and talk. Based on these data, development screening in every child is important for early detection so that immediate intervention can be carried out before abnormalities occur. Several literatures, stated that intervention in children with suspicion of developmental deviation should be done before the age of 3 years old.

There are several tools/ methods available for screening development in a child. Capute Scale (Cognitive Adaptive Test/ Clinical Linguistic Auditory Milestone Scale - CAT/ 
CLAMS), which has been standardized is to use. Developmental screening with Capute Scales can assess accurately key aspects of development including language and visual motor components. [5] This method can assess the quantification of Development Quotient (DQ) which provides a differential diagnosis of a child's developmental disorder. [6] It's quick and easy measurement of developmental aspects can help establishing differential diagnosis of developmental disorders (delayed, deviation and dissociation) in infancy and early childhood, so that early intervention can be done immediately to give its best results. Capute Scales has been used widely for clinical assessment of neurodevelopment by pediatricians. [5] The usage of Capute Scales in primary service care is still limited, special training is needed, so that it can be used correctly by health workers in primary care.

Limited time, knowledge and skills in screening are the causes of few doctors whom perform routine screening at the practice. Only about $30 \%$ pediatricians in the United States perform the screening formally. One method that is very easy and quick to detect early developmental deviations is the time, as well as expand the scope of early detection of development, the early stages of screening can be perform by nurses or trained medical personnel by using pre-screening questionnaires for parents, then determine children whom need further formal evaluation. [7-8] Frankenburg et al (1981), developed the Prescreening Developmental Questionnaire (PDQ) from Denver Developmental Screening Test (DDST). This PDQ form was translated and modified by a team from Republic Indonesia Health Ministry in 1996, then revised in 2005, which is known as Kuesioner Praskrining Perkembangan (KPSP) and can be done by health workers or non-health workers who are trained. [9-10]

A pre-screening device must has validity, reliability, sensitivity, specificity, acceptability and suitability to local conditions. Validity and reliability are parameters to determine the quality of the instrument, while sensitivity and specificity are measured by comparing developmental test to its gold standard, thus far there hasn't any study which determine the effectiveness of KPSP with Capute Scales as the gold standard. Researchers want to conduct a study to determine the sensitivity, specificity, positive predictive value and negative predictive value of the examination method. pre-screening method. To reduce unnecessary expenses and

\section{Methods}

This is a diagnostic test that used a cross sectional design. This study began by determining the affordable population as sample and then the subjects were examined by KPSP and Capute Scales. The study was conducted in South Denpasar Health Center from March until May 2018. Inclusion criteria were children aged 3 - 24 months old and parents agreed to participate in the study. Exclusion criteria were children with Down syndrome, congenital hypothyroidism, cerebral palsy, suspected of autism spectrum disorder and major congenital disorders such as congenital heart defects. Calculation of sample size used the formula of sample size for diagnostic tests. [11] The sensitivity was set at $80 \%$. The width of the deviation of the $p$ value that is still acceptable was $20 \%$. The prevalence of deviation based on Capute Scales was 0.13 based on the literature. [12] Researchers hypothesis that KPSP has a minimum diagnostic value of $80 \%$. The minimum number of samples needed in this study was 118 samples.

Subject characteristics include gender, age, nutritional status, parental education history and parental occupation. This study used a cut-off point 6 to determine whether there is a risk of deviation based on KPSP. It is categorized as a developmental deviation if the total score was 'Yes' $\leq 6.9$ Assessment with Capute Scale used a cut-off point 85 . A developmental disturbance was ruled out when DQ $\leq 85$. The obtained data was processed into SPSS software program, then calculated in table $2 \times 2$ to get the sensitivity, specificity, positive predictive value and negative predictive value.

\section{Results}

This study subjects were 127 out of 132 children whom met the inclusion criteria. Most subjects were male with an average age 11.7 months. The most nutritional status was well nourished. The education level of both fathers and mothers, were dominated by high school graduates. $74 \%$ of mothers were housewives (Tabel 1).

The sensitivity, specificity, positive predictive value and negative expected value of KPSP tool in detecting irregularities with Capute Scales as the gold standard (Tabel 2).

Table 1. Subject characteristic.

\begin{tabular}{llll}
\hline Variabels & Deviation $\mathbf{n}=\mathbf{8}$ & Normal $\mathbf{n}=\mathbf{1 1 9}$ & Total $\mathbf{n}=\mathbf{1 2 7}$ \\
\hline Gender, n (\%) & & & \\
Male & $5(62,5)$ & $66(55,4)$ & $71(55,9)$ \\
Female & $3(37,5)$ & $53(44,5)$ & $56(44,1)$ \\
Age, months old, average (SB) & $19(5,0)$ & $11,5(6,6)$ & $11,7(6,6)$ \\
Nutritional status, n (\%) & $2(25,0)$ & $16(13,4)$ & $18(14,2)$ \\
Malnourished & $6(75,0)$ & $90(75,6)$ & $96(75,6)$ \\
Normal & $0(0,0)$ & $9(7,5)$ & $9(7,1)$ \\
Overweight & $0(0,0)$ & $4(3,4)$ & $4(3,1)$ \\
Obesity & & & \\
Paternal level of education, n $(\%)$ & $0(0,0)$ & $7(5,9)$ & \\
Elementary & $3(37,5)$ & $19(15,9)$ & $22(17,3)$ \\
Junior high school & & & \\
\hline
\end{tabular}




\begin{tabular}{|c|c|c|c|}
\hline Variabels & Deviation $n=8$ & Normal $n=119$ & Total $n=127$ \\
\hline Senior high school & $4(50,0)$ & $73(61,3)$ & $77(60,6)$ \\
\hline University & $1(12,5)$ & $20(16,8)$ & $21(16,5)$ \\
\hline \multicolumn{4}{|c|}{ Maternal level of education, $\mathrm{n}(\%)$} \\
\hline Elementary & $0(0,0)$ & $12(10,0)$ & $12(9,4)$ \\
\hline Junior high school & $5(62,5)$ & $23(19,4)$ & $28(22,0)$ \\
\hline Senior high school & $2(25,0)$ & $70(58,8)$ & $72(56,7)$ \\
\hline University & $1(12,5)$ & $14(11,8)$ & $15(118)$ \\
\hline Jobless & $0(0,0)$ & $1(0,84)$ & $1(0,8)$ \\
\hline Labor & $0(0,0)$ & $13(10,9)$ & $13(10,2)$ \\
\hline Government employee & $1(12,5)$ & $13(10,9)$ & $13(10,2)$ \\
\hline Entrepeneur & $7(87,5)$ & $90(75,6)$ & $97(76,4)$ \\
\hline Others & $0(0,0)$ & $3(2,5)$ & $3(2,4)$ \\
\hline \multicolumn{4}{|c|}{ Paternal occupation, n (\%) } \\
\hline Housewive & $8(100)$ & $86(72,3)$ & $94(74,0)$ \\
\hline Entrepeneur & $0(0,0)$ & $26(21,8)$ & $26(20,5)$ \\
\hline Others & $0(0,0)$ & $1(0,8)$ & $1(0,8)$ \\
\hline
\end{tabular}

Table 2. Diagnostic test result.

\begin{tabular}{|c|c|c|c|c|c|c|}
\hline \multirow{2}{*}{ KPSP } & Capute & Scales & \multirow{2}{*}{ Sen $(\%)(95 \% C I)$} & \multirow{2}{*}{ Spe $(\%)(95 \% C I)$} & \multirow{2}{*}{ PPV (\%) (95\%CI) } & \multirow{2}{*}{ NPV (\%) $(95 \%$ CI $)$} \\
\hline & Deviation & Normal & & & & \\
\hline Deviation & 6 & 1 & \multirow{2}{*}{$75(40,9-92,8)$} & \multirow{2}{*}{$99,1(95,3-99,8)$} & \multirow{2}{*}{$85,7(48,6-97,4)$} & \multirow{2}{*}{$98,3(94,1-99,5)$} \\
\hline Normal & 2 & 118 & & & & \\
\hline
\end{tabular}

\section{Discussion}

To date there has never been a similar research comparing the validity of KPSP with Capute Scales as the gold standard in detecting developmental deviations. Based on the assessment results of developmental status in children aged 3-24 months old at the South Denpasar Health Center using KPSP, $5.5 \%$ of subjects were suspected of developmental deviations while with Capute Scales there were much more, that was $6.3 \%$. The number of deviation was quite low in this study, it could be due to the majority of subject's mothers were not working (as housewives) so that they had more time in paying attention to children.

A good development test must has sensitivity and specificity more than $70-80 \%$ in order to avoid overdetection or underdetection. [7-8] The result of this study was compared with Capute Scales, KPSP had a sensitivity of $75 \%$ and specificity of $99 \%$. Other studies had different results, the sensitivity and specificity values of KPSP were found to be slightly lower at $60 \%$ and $92 \%$, but with Denver II as the gold standard. [10] Kadi FA et al, found that KPSP examination was moderate to Denver II and can be used as an early detection tool in Posyandu. [13] The sensitivity value was $95 \%$, specificity $63 \%$, kappa value $0.552, \mathrm{p}<0.0001$, indicating that KPSP can act as pre-screening tool in detecting developmental deviations. Kuesioner Praskrining Perkembangan (KPSP) is a frequently used tool in screening child development in addition to the Parent's Evaluation Developmental Status (PEDS) and Denver II test. Artha NM et al, showed KPSP and Denver II test had good agreement with kappa value 0.6 , in almost all aspects of development. [14] In contrast to the kappa value between KPSP and PEDS which was lower, 0.17; PEDS and Denver II amounted to 0.29.
The easy inspection method of KPSP allows this examination to be carried out routinely in primary care so that any developmental deviations in children can be detected early.

\section{Conclusion}

Kuesioner Praskrining Perkembangan (KPSP) has good sensitivity and specificity to detecting developmental deviations in children with Capute Scales as the gold standard.

\section{References}

[1] World Bank. Repositioning nutrition as central to development: a strategy for large-scale action. Washington, DC: World Bank, 2006.

[2] Khadijah. Pengembangan kognitif anak usia dini. Medan, Perdana Publishing: Kelompok Penerbit Perdana Mulya Sarana, 2016.

[3] Kementerian Kesehatan Republik Indonesia. Menuju Masyarakat Sehat yang Mandiri dan Berkeadilan. Jakarta, 2010.

[4] Suwarba IGN, Widodo DP, Handryastuti RAS. Profil klinis dan etiologi pasien keterlambatan perkembangan global di Rumah Sakit Cipto Mangunkusumo Jakarta. Sari Pediatri. Vol. 10, No. 4, 2008, pp. 255-61.

[5] Dhamayanti M, Herlina M. Skrining gangguan kognitif dan bahasa dengan menggunakan Capute Scales (Cognitive Adaptive Test/Clinical Linguistic \& Auditory Milestone Scale-Cat/Clams). Sari Pediatri. Vol. 11, 2009, pp. 189-98.

[6] Leppert MLO. Development of the capute scales. Accardo PJ, Capute AJ. The capute scales: adaptive test/clinical linguistic \& auditory milestone scale. Baltimore; Paul H. Brookes Publishin Co. 2005 , pp. 1-8. 
[7] American Academy of Pediatrics, Committee on Children with Disabilities. Developmental surveillance and screening of infant and young children. Pediatrics. Vol. 108, 2001, pp. 192-6.

[8] Blackamn JA. Developmental screening: infant, toddlers and preschoolers. Dalam: Levine MD, Carey WB, Crocker AC, penyunting, Developmental-behavioral pediatrics. Edisi ke 3. Philadelphia: Saunders. 1999, pp. 699-95.

[9] Kementerian Kesehatan Republik Indonesia. Pedoman pelaksanaan stimulasi, deteksi dan intervensi dini tumbuh kembang anak ditingkat pelayanan kesehatan dasar. Jakarta, Bakti Husada: Direktorat Jendral Pembinaan Kesehatan Masyarakat, 2012.

[10] Dhamayanti M. Kuesioner Kuesioner pra skrining perkembangan (KPSP) anak. Sari Pediatri. Vol. 8, No. 1, 2006, pp. 9-15.
[11] Dahlan S. Statistik untuk kedokteran dan kesehatan. Jakarta: Salemba Medika, 2010.

[12] Hertanto M, Shihab N, Ririmasse MP, Ihsan N, Rachmasari M, Wijaya MT, et al. Sari Pediatri. Vol. 11, No. 2, 2009, pp. 130-5.

[13] Kadi FA, Garna H, Fadlyana E. Kesetraan hasil skrining risiko penyimpangan perkembangan menurut cara kuesioner praskrining perkembangan (KPSP) dan Denver II pada anak usia 12-14 bulan dengan berat lahir rendah. Sari Pediatri. Vol. 10, No. 1, 2008, pp. 29-33.

[14] Artha NM, Sutomo R, Gamayanti IL. Kesepakatan hasil antara kuesioner pra skrining perkembangan, parent's evaluation of developmental status, dan tes Denver-II untuk skrining perkembangan anak balita. Sari Pediatri. Vol. 16, No. 4, 2014, pp. 266-7. 